\section{Education, the Nation State and the Global Economy}

\author{
PHIL BROWN AND HUGH LAUDER
}

\section{Abstract:}

There is a consensus amongst policy makers that education can provide the solution to the fundamental problem of liberal democracies - how to reconcile social justice with economic efficiency at a time when income and wealth are being polarised in Anglophone-dominated societies like Aotearoa New Zealand. This presents a paradox, since it is well understood that children living in poverty are likely to under-perform in education. Moreover, the standard explanation for the polarisation of income in terms of the global demand for skill is itself deficient. This paper explores the nature of this paradox, and the inadequate account given for polarisation of income, as a first step towards the develop-ment of an alternative agenda which is more likely to meet the goals of justice and efficiency in the context of the new global competition.

n the past two decades there has been a transformation in the nature of the global economy and a fundamental change in the structure of work. The dominant parties of the political right and left in countries such as New Zealand, Britain and America have drawn two conclusions from these changes. The first is that nation states are now limited in the way they can determine the well-being and life chances of their citizens, in contrast to the situation in the post-war period, between 1950-1973, when Keynesian demand management could ensure near full employment. The second is that education is the key to individuals' prospects in the new global economy because of the premium placed on highly-skilled labour. It is noted, for example, that it is the unskilled who are more likely to be unemployed and in poverty. Therefore, since the one area where the state still has a high degree of control is over education, it is education which should take centre stage in the formulation of a nation's economic and social policy. It is thinking of this kind which led to the publication of the celebrated Nation at Risk

\section{Phil Brown and Hugh Lauder}

manifesto in the United States in the early eighties, and to the same title being used to promote the National party's education policy in New Zealand in 1990. In one sense the education system is now being asked to provide the solution to the fundamental problem of liberal democracies: how to reconcile social justice with economic efficiency. By creating a highly skilled workforce, it is argued that the issue of economic survival is addressed since it is nations with highly educated workforces which will attract "high quality" direct inward investment, in the creation of leading edge industries. Full employment will, thereby, be achieved, and as an added bonus, work in these enterprises will be cognitively stimulating. Moreover, the question of social justice is addressed by emphasising the need to raise educational standards for all, thereby ensuring access to high skill, high waged jobs. Notice, that this could be a definition of equity, but certainly not of equality of opportunity in the strong sense of equality of results formulated by Coleman (1968). ${ }^{2}$ Politically, and in terms of life chances, this shift in definition has significant consequences for how education policy is framed and for the viability of the now conventional position in political rhetoric espoused by the centre left and right. ${ }^{3}$

The purpose of this paper is to point out a paradox in this position which makes it untenable, and to provide an argument for an alternative agenda in social and economic policy which has the potential to address, more adequately, the reconciliation of social justice and economic efficiency under the new global economic conditions. To understand this paradox we need to note that there is a consensus amongst politicians and policy makers of the centre left and right that the polarisation of incomes and wealth in western societies over the past twenty years can be explained in terms of skill. It is asserted that the global demand for highly skilled occupations has risen, while the demand for unskilled work has fallen. Hence, as the well-educated are getting well-paid jobs, the least well-educated have experienced a decline in wages, or unemployment. And here it should be borne in mind that New Zealand has polarised more rapidly than any other western society in the recent past (Hills, 1995). The fact of polarisation, therefore, gives an added urgency to the question of social justice and makes it all the more important that the claim that education can narrow the gap between rich and poor be thoroughly examined.

Given this background, the paradox can be simply stated. How is it possible to even meet the goal of equity as defined above when in the neo-liberal societies of New Zealand, America and Britain, the consequence of polarisation has meant that somewhere between 20 and 
30 per cent of children live in poverty. It is one of the well-established findings of social science research that those who come from households in poverty do not, by and large, achieve well in education. How, under these conditions is the goal of educating all potential citizens to a high standard to be met? But asking this straightforward question really only begins the process of showing how flawed this position is. For in order to claim that polarisation is a function of changes in the global demand for skill, these politicians and policy makers assume the commonly held, but inadequate, neo-classical economic assumptions about the nature of skill in the labour market. Hence, they cannot explain why polarisation has occurred, and they have, therefore, little understanding of why a "sound" education for all cannot be achieved within the framework of policies they articulate. Nor why, even if we entertained the implausible idea that it could be achieved, it would not remedy the problem of social justice.

The argument developed in this paper rejects the idea that polarisation of wealth and income is to be explained primarily in terms of changes in the global labour market, arguing rather that the extreme polarisation experienced in Anglophone-dominated economies is a function of the neo-liberal political project initiated during the eighties. Rather than being a natural consequence of changing global demand for skill, polarisation should be seen as the neo-liberal state's response to the new global economy. The state, therefore, has the potential for playing a far more active role in reducing the disparities of wealth and income in neo-liberal societies.

However, while the state can profitably intervene to reduce the disparities of wealth and income for those in work, the situation for those out of work is somewhat different. The cause of high and persistent levels of unemployment is less to do with the question of skill, and more to do with the development of a standard economic policy response to the global economy which locks in high levels of unemployment. Again, there is a radical state response which can address this issue in ways that have not been contemplated in Anglophone-dominated societies, one which is necessary if we are not to accept the alternative of an underclass with all the undesirable consequences its existence has, for society in general, and education in particular.

Taken together, interventions to reduce the polarisation of income and wealth and address the issue of unemployment can bring about the social foundations to provide a greater measure of equality of opportunity. However, we also need to consider the nature of education policy advocated by the consensus view. Essentially, it can be interpreted in two ways, both of which see the state as stepping back from its role of regulating the competition for credentials on a just basis. The strong interpretation of this retreat is that by introducing market competition, the state is actively giving the professional middle class the advantage necessary to reproduce its privilege from one generation to another (Brown, 1990; 1995). The weaker but no less important argument is that by emphasising raising standards for all the state simply remains silent on the question of how the competition for credentials is to be fairly regulated. Equity has replaced equality of opportunity. Moreover, in both interpretations the question of the social conditions necessary to bring about even the minimal condition of equity is transferred by a sleight of political rhetoric into a question about school effectiveness. Schools, against all the evidence, are supposed to be able to compensate for society. The policy alternatives to this retreat by the state point to an active role for the state in fairly regulating the competition for credentials, as well as providing the social conditions to enable all children to achieve a sound education.

In order to understand why this now conventional vision is flawed, although no doubt politically attractive, we "interrogate" it by examining the issues of income polarisation, unemployment and the regulation of the competition for credentials.

\section{Income Polarisation and the Global Labour Market}

According to the new consensus, growing income inequalities are seen to reflect individual differences in the quality of their "human capital". Here the argument is based on trend data which show a widening of income inequalities. There has been a dramatic increase in income inequalities in New Zealand, America and Britain since the late 1970s. Such evidence is taken to reflect the relative abilities of workers to trade their knowledge, skills and insights on the global labour market. As low skilled jobs have been lost to developing economies with cheaper labour, the wages of less skilled workers in the West have declined. By the same token, in the new competitive conditions, those workers who have the skills, knowledge and insights that can contribute to "value added" research, production, consultancy or service delivery in the global labour market have witnessed an increase in their remuneration. Hence analysis and remedy are closely related in this account: if the reason so many workers are in low paying jobs, or worse, unemployed, is that they lack skills, the solution is to give them the skills. It's an appealing analysis, but at best it is based on a partial truth. 
If increasing income polarisation was a consequence of the neutral operation of the global economy we should find the same trend in all the advanced economies. However, the evidence suggests that the increasing polarisation in income is far more pronounced in America and Britain than in any other OECD country (Gardiner, 1993, p. 14; Hills, 1995). In Germany there has actually been a decline in income differentials! (OECD, 1993).

It could also be expected that if the increased dispersion of income was a result of the changing cognitive and skill demands of work, then nations with the highest levels of technology and investment in research and development would lead the table of income inequalities. Yet, the evidence that does exist suggests quite the opposite. Wood (1994) notes that, "Japan and Sweden are leaders in applying new technology, while the USA and UK are laggards" (p. 281). He also notes that the work of Patel and Pavitt (1991) suggests that civilian research and development, as a proportion of GDP in the 1980s, was higher in Sweden and Japan than in the USA and the UK. Equally, in terms of taking out patents in the USA, Germany, which experienced declining inequalities of income during this period, greatly outperformed the UK.

One conclusion to be drawn from these considerations is that rather than the returns to skill becoming more responsive to the operation of the global auction, the relationship between skill and income is less direct than politicians and policy makers assume, the reason being that the relationship between income and skills is always mediated by cultural, political and societal factors. This is of course obvious when unpaid child care, undertaken primarily by women, is taken into consideration. Moreover, despite the way skill is used in the current debate about income inequalities and economic performance, it has proved extremely difficult to arrive at an agreed definition of skill. Studies comparing labour markets in neighbouring countries like Germany and France show that the process of training, career progression and reward for skills is intricate, subtle and substantially different in the two countries (Maurice et al., 1986). Another study by Dore (1987) has highlighted differences in the way rewards are distributed for work in America as opposed to Japan. In America it is assumed by neo-classical economists and entrepreneurs that there is a direct relationship between skill and income. However, Japanese industry has not organised the relationship between skill and income in this direct way. Rather, it has based income on loyalty to the company and length of service, rather than "skill" in any pristine sense. As Dore has noted, in Japan there is a remarkable "lack of consciousness of the market price of a skill" (p. 30). This being the case, it could be expected that even if the polarisation of income in America was a response to the changing demand for skill, this would not be the case in Japan. A further glance at the OECD (1993) data also tells us that while there has been some widening of income differentials in Japan, it does not reflect the polarisation characteristic of the United States and Britain.

What this evidence suggests is that the assumption that by raising skill levels there will be a commensurate increase in income regulated through the global labour market is clearly incorrect. The answer is to be found not in the neutral operation of the global labour market as Reich (1991) and others have suggested, but in the way New Zealand, the United States and Britain have responded to global economic conditions. This response, like the global economy itself, has been shaped by the New Right political projects of Reagan and Thatcher (Marchak, 1991). Although the debate about what is distinctive about America and Britain takes us beyond the confines of this paper, the polarisation in income can be explained more convincingly in terms of differences in labour market power rather than returns to skills (although they are not entirely mutually exclusive). A major consequence of market deregulation in the Anglophone-dominated societies has been to enhance the power of "core" workers in down-sized organisations. This is supported by the fact that the most dramatic changes in income distribution are to be found at either end of the income parade. What income polarisation in New Zealand, the USA and the UK also reveals is the way in which the "casino" economies of these countries in the 1980s enabled company executive and senior managers, along with those who worked in the financial markets, to engage in "wealth extraction" rather than the development of sustainable forms of "wealth creation" (Lazonick, 1993). This largely explains why a study reported by Bound and Johnson (1995) found that in America a large part of the increase in the returns to a university degree was due to an increased premium put to use in the business and law fields. The wages of computer specialists and engineers actually fell relative to those of high school graduates

But if the rising incomes of the work-rich are explicable in terms of "paper entrepreneurialism" (Reich 1984) and corporate restructuring, can the decline in the wages of the unskilled be explained in terms of the neutral operation of the global economy? In addressing this question there is the problem of measuring the extent to which semi-skilled and unskilled work have been transplanted to the developing nations. One estimate is that, up to 1990, changes in trade with the South have 
reduced the demand for unskilled (relative to skilled) labour in the North by approximately 20 per cent (Wood 1994, p. 11). However, it is not only that industrial blue collar jobs were lost, but the perennial threat of relocation to developing world countries, which ensured that wages were depressed for remaining unskilled workers. It is, of course hard to measure the degree to which this threat has been material in keeping down wages. Nevertheless, it is worth noting that there is little correlation between manufacturing competitiveness and low wages. In the most successful industrial economies, Germany and Japan, manufacturing wages are higher than anywhere else. However, New Right governments took the "lesson" of neo-classical economists to heart, and helped to drive down wages by labour market deregulation. Estimates for the UK (Gosling \& Machin, 1993) and the USA (Blackburn, Bloom \& Freeman, 1990), for instance, calculate that the decline in unionisation over the 1980s accounts for 20 per cent of the increase in wage inequality. It could, of course be argued that government action in breaking the power of unions by deregulation really was a post hoc manoeuvre by neo-liberal governments simply because the power of unions was already undermined by the threat of competition for cheap manual labour from overseas. However, while there may be some truth to this, there are two observations to be made. Not all OECD states took this route and suffered as a result, despite the continued triumphalism of the New Right who have predicted their imminent economic demise. More importantly, the fastest growing sector of the economy (the service sector) is relatively immune from international competition, especially in lower paid jobs. Hence this argument simply does not apply, at least not in any straightforward sense.

What labour market deregulation did was to make it easier to hire and fire workers, and enabled companies to achieve numerical flexibility in terms of their wages bills (Atkinson, 1985). At times of economic boom, workers could be hired, while in times of downturn they could be fired. In Britain, for example, in the last three months of 1994, 74,120 full-time jobs disappeared and 173,941 part-time jobs were created. This is a clear example of how to organise a labour market for short-term expedience, but it also suggests that companies have not only externalised the risks associated with unstable market conditions but also their labour costs, especially among low skilled workers. In such circumstances it is difficult to see how the problem of widening income inequalities can be solved when they are judged to reflect the neutral operation of the global economy.
In effect the commitment to wealth extraction rather than long term wealth creation, often called producer capitalism, has generated the conditions for low pay and insecurity over and above state deregulation of the labour market. In an important respect the high rates of wealth extraction by senior executives and managers in the private and quasi private sectors, the emphasis on numerical flexibility and neo-liberal policies of redistribution in favour of the rich, while deregulating labour markets, can be seen as part of the overall pattern of persistent failure of the Anglophone-dominated economies (Hutton, 1995). Short-term indicators of economic success there might be, but they should not be read as an upward trend towards a society which can reconcile social justice and economic efficiency, precisely because the long-term investment in capital and labour is absent.

The absence of a long-term investment in labour is of particular concern, especially if we are interested in providing a sound education for all. The fact is that one thing we know about educational success is that its springboard is a secure childhood. Parents who are constantly suffering financial insecurity are less likely to be able to create the necessary security for their children. The situation for the unemployed, however, is even more problematic, and it is to them we now turn.

\section{Unemployment and Reskilling}

The consensus view is that the state can no longer guarantee full employment. It can, however, provide for high skill, high wage, full employability through education in the future. However the problem here is that the high wage, if not the high skill route, may nevertheless be pursued at the price of significant unemployment in the short to medium term. This is because, historically, education systems have not been geared to providing high levels of education for all, so that the only way high wages for the semi-skilled and unskilled can be maintained is through various forms of labour market regulation and social protection policies. However, as we have seen, according to neo-classical economists, labour market regulation bids up the price of those in work and discourages employers from taking on more workers. With deregulation the price of labour would fall and employers would "buy" more workers. The debate over labour market deregulation has given rise to the view that all advanced societies are now on the horns of a dilemma in terms of unemployment. Either labour markets are deregulated as in America, where official unemployment is below 5 per cent, but where there is extensive poverty because wages at the bottom end of the labour market are insufficient to live on, or they are 
regulated, as in the producer capitalist route pursued by Germany, where unemployment is higher but so is the compensation paid to the unemployed (European Commission, 1993; Freeman, 1995). The problem this poses is that on the one hand a majority of workers can expect good quality jobs and a reasonable standard of living, but the polarisation of market incomes avoided by the producer capitalist route, espoused in northern Europe, is reproduced between those in work and those unemployed. The divisions in society remain, but the source is different.

The problems with these arguments are that the binary options of full employment vs. full employability and of regulated vs. deregulated labour markets fail to grasp the causes of unemployment in the late twentieth century. Unemployment, at the low levels achieved during the post-war period was historically unique, depending on a contingent set of circumstances (Ormerod, 1994). Attempting to create similar circumstances for the early part of the twenty-first century is likely to prove elusive and in political terms something of a hoax perpetrated by political parties who promise it, or something close to it. It is, perhaps, for this reason that full employment has been translated into full employability, thereby throwing the onus on the individual to find a job.

If we examine the profiles of several OECD countries, there are two striking observations that can be made. Firstly, GDP has been divorced from employment in the past twenty years, just as growth has not led to a shared prosperity during the same period. In Spain the economy grew by 93 per cent between 1970-1992 and lost 2 per cent of its jobs (Financial Times, 1993, October 2). This is in stark contrast to the post-war period when both incomes and jobs were linked to economic growth. Growth delivered an even rise in income for all occupational groups. Secondly, the trajectories taken by OECD countries in terms of their main indicators, inflation, growth and balance of payments vary dramatically, yet unemployment remains around or above 7 per cent, in terms of the official statistics, for every country with the exception of America and Japan. This includes countries with recent relatively high levels of growth such as Canada, New Zealand and Australia. ${ }^{4}$

What appears to have happened in the past 25 years is that a set of economic and social forces has pushed the lower limit of unemployment up substantially from an OECD average well below 5 per cent in the post-war period to an average well above 7 per cent. Clearly the oil price hikes of the early seventies had much to do with the initial jump in unemployment, but since then a series of contingent factors has conspired to lock unemployment in at this high level. The introduction of new technology which has enabled machines to replace workers could have had a significant impact on unemployment for both blue and white collar workers as the jobless growth in Spain suggests. Similarly the number of blue collar jobs lost to the developing nations has added to the problem (Wood, 1994). However, these factors have to be placed within the wider context of economic regulation in relation to the global economy. It is worth noting that current economic orthodoxy ensures that interest rates rise with economic growth, thereby potentially choking off further investment in productive capacity and hence employment. It may also reduce demand, especially in countries like America and Britain with a high proportion of families with mortgages.

There are two mutually consistent explanations for the link between rising interest rates and growth. The first is that in a deregulated global finance market there is a shortage of investment funds, especially at times of growth. After all, with the potential to invest in developing nations, as well as the developed nations, the competition for investment has increased dramatically. Moreover, in a global economy, the business cycles of the developed and developing nations are likely to be more synchronised, so that an upturn in the global economy is likely to be met by a global demand for increased investment (Rowthorn, 1995). The second is that, within nations, the key instrument for the control of inflation is interest rates. As economies overheat, interest rates are raised by central banks to choke off demand. The use of interest rates to control inflation is claimed to be successful in controlling inflation in a way in which other measures tried in the seventies and eighties - incomes policies and control of money supply - were not. Again, however, we should note the role of the new global economy in defining the control of inflation as a key element in any successful national competitive strategy. If inflation in any one country rises to appreciably higher levels than in competitor countries, its goods are likely to be priced out of the market. Hence the significance accorded to the control of inflation in a global economy. But the cost of using interest rates to this end is that economies are run in a permanent state of under-capacity (ILO, 1995, p. 163). The rise in interest rates simply chokes off demand before it can appreciably effect unemployment levels.

More recently, other studies have argued that it is declining economic growth (and hence demand) among the OECD countries since 1973 which is the fundamental cause of unemployment (ILO, 1995; Eatwell, 1995). While the trend in economic growth in all OECD countries has declined (ILO, 1995, p. 133) it is unclear whether raising 
levels to those which prevailed in the period between 1960-73 would have the same impact on unemployment now that it did then, as the examples of Australia and Canada show. The problem is that in a global economy, growth may be achieved through exports, and the benefits of growth spent on imports rather than home-produced goods. Whereas, in the post-war Fordist economies a rise in demand would percolate through the economy, thereby creating jobs, a rise in demand now may simply create jobs in some other part of the world. This may be especially so in countries where increases in incomes are accruing to the wealthy, who spend their money on luxury goods from overseas.

The alternative to this macro-analysis of the causes of unemployment is the micro-analysis of some neo-classical economists, who argue that it is labour market rigidities, of the kind discussed above, especially the power of trade unions and highly regulated labour markets, which cause unemployment and sustain inflation. There are two elements to their explanation. The first is that these rigidities bid up the price of labour and maintain it at a level higher than desirable to clear the labour market of unemployed. The second is that these rigidities allow the "insiders" who are employed to bid up their wages even when others are unemployed (Lindbeck \& Snower, 1986). There are two problems with this theory. Firstly, there appears to be no strong historical relationship between the degree of social protection, labour market regulation and unemployment. The lowest levels of unemployment, 1950-1973, have been associated with the highest levels of social protection and labour market regulation, while the present period represents one of the lowest levels of protection and regulation and the highest levels of unemployment. In itself this particular argument is not strong if we assume, as neo-classical economists tend not to, that there has been a fundamental shift in the economic, social and political conditions of western economies in the past twenty years. For these changed conditions may bring about changes in the relationship between degrees of regulation and social protection and employment. However even within the current period, differences between nations relating to regulation, protection and economic performance hardly bear out this thesis. For example, the UK has one of the lowest levels of labour protection in the OECD and an unemployment rate of 8.4 per cent in the past year ${ }^{4}$ (OECD, 1994, p. 155). In contrast, Holland, which has an above average level of protection and regulation has an unemployment rate of 7.3 per cent. Moreover, their inflation rates are not substantially different. Britain has had an annual rate of 2.4 per cent in the past year and Holland 3 per cent. Secondly, where labour markets have been de-regulated, it is unclear that they have genuinely achieved the benefits that appear to have resulted. Poverty amongst those on low wages in the United States is high, and it has been argued that there is a de facto policy of incarceration of the unemployed (Freeman, 1995). New Zealand stands out as a possible exception; however analysis has still to be done to see whether the same phenomenon of the "working poor" is occurring. We know that New Zealand has the highest level of polarisation of income within the OECD, which may indicate that the phenomenon of the working poor may indeed exist. And we know that there are high levels of incarceration of Maori. Until the research is done on these issues the jury remains out. ${ }^{5}$

Overall, it seems extremely unlikely that the problem of unemployment can be solved by any of the conventional remedies, and to pretend otherwise merely holds out false promises to a generation of unemployed. The New Right solution was to price people backinto jobs. The producer capitalist solution is to create a high skill, high wage economy. Neither solution is adequate. The New Right solution manifestly has not worked, and it threatens a new cycle of low-wage job creation. The producer capitalist economies, whilst having a more sustainable approach to global economic competition, have no answer to unemployment. Therefore, the most important conclusion to be drawn from this discussion is that Western capitalist nations lack an adequate account of how all will share in the future prosperity accrued from investment in education and national economic growth. Unemployment will remain a structural feature of Western societies, and the "distributional" question (Hirsch, 1977), ${ }^{6}$ temporarily solved under Fordism through full employment and the even spread of the fruits of growth across the occupational structure, must now be addressed. Consequently, we argue elsewhere (Brown \& Lauder, forthcoming) that the distributional problem can only be remedied by the introduction of a citizen's or social wage, and that occupational opportunities will have to be shared. However, the question of unemployment is not only one about social justice, but one of educational opportunity and economic efficiency. If the economic fate of nations increasingly depends upon the quality of their human resources, it will not be possible to write off a large minority of the population to an "underclass" existence. Therefore, we need to ask how those people living in poverty are going to acquire the appropriate skills to get high skilled, high waged jobs, when research has demonstrated that social deprivation has a profoundly negative impact on academic performance. 


\section{Poverty and the Competition for Credentials}

It is commonly recognised that ways must be found to develop the full potential of a much larger proportion of the population than prevailed in the Fordist era. Most agree, often in spite of their ideological allegiances $^{7}$ on the need to widen access to tertiary education and to create the institutional framework necessary to offer life-long learning to all. A national commitment to investment in the "employability" of present and future workers is understood to represent a new social contract between the individual and the state, given that such investment is viewed as a condition for economic efficiency and social justice. However, the interpretation of how equity and efficiency is to be achieved in the global economy is politically impoverished. In part, this is because the question of equality of opportunity has been subsumed within a debate about how to upgrade the overall quality of education and training systems, based on an assumption that domesticinequalities of opportunity are largely irrelevant if a nation can win a competitive advantage in the global knowledge wars, permitting all to compete for high skilled, high waged jobs. Therefore, the old national competition for a livelihood, based on the principles of meritocratic competition, is of far less importance than that of how to upgrade the quality of the education system as a whole. Equity, the right to a sound basic education, is substituted for equality of opportunity and thereby the political sting is extracted from questions of social and educational inequalities.

The reality is that questions of social justice cannot be resolved through the operation of the global labour market. Indeed, if the creation of a high skill, high wage economy depends on a general upgrading of the skills of the labour force, tackling the problem of domestic inequalities in income and opportunities has become more, rather than less, important with economic globalisation. There are at least two related reasons for this. Firstly, the use of education and training institutions to raise technical standards for all does not resolve the question of "positional" advantage (Hirsch, 1977). In other words, access to elite schools, colleges, universities, along with the credentials they bestow, remains a key factor in determining labour market power. In addition, if our analysis of income inequalities is correct, individual labour market power has, if anything, become more important as a result of corporate restructuring and the decline of graduate careers (Brown \& Scase, 1994). Therefore, the question of social justice will continue to depend on how individual nation states frame the competition for a livelihood.
The question of positional competition has also become more important because there has been a change in the nature of educational selection. Today the institutional expression of a commitment to meritocratic competition has been abandoned in favour of consumer sovereignty, based on parental "choice" and on a highly devolved system of educational resourcing based on market principles. A consequence of this change in the organisation of educational selection from that based on "merit" to the "market" (Brown, 1995) is that it serves to encourage the polarisation of funding, curriculum choice, and teacher and student morale between schools in areas of high unemployment and low market income, and those in middle class areas.

Avoiding the positional problem by appeals to the need to raise educational standards for all in the global market fails to address the question of the polarisation of educational resources. But it also offers little insight into how the foundations for social solidarity, upon which an institutional expression of meritocratic competition rest, are to be rebuilt. Indeed, the focus on increasing the "employability" of workers reinforces a sense of the insecure nature of work at the end of the twentieth century (Newman, 1993; Peterson, 1994). It encourages people to constantly watch their backs and to put their own children first in the educational and labour market jungle. Without an adequate foundation for material and social security the emphasis on enhanced employability within a culture of competitive individualism becomes translated into the Hobbesian condition of "all against all". When education becomes a positional good, and where the stakes are forever increasing in terms of income, life-chances and social status, powerful individuals and groups will seek to maximise their resources to ensure that they have a stake in the game, by whatever means. Therefore, how the state intervenes to regulate this competition in a way which reduces the inequalities of those trapped in lower socio-economic groups must be addressed, not only as a matter of economic efficiency but also for reasons of social solidarity and justice.

The relationship between equality of opportunity and efficiency at the end of the twentieth century not only rests on the reassertion of meritocratic competition in education, but on a recognition that the wealth of the nation's human resources is inversely related to social inequalities, especially in income and opportunity. Therefore, narrowing such inequalities is likely to be a cost-effective way of investing in human capital, which in turn should lead to improvements in economic efficiency. Hence, we would predict that the polarisation of income in the Anglophone-dominated nations during the eighties will have led to 
a wider dispersal of educational achievement than in nations with little or no widening of incomes. We are currently analysing the comparative evidence in order to examine the hypothesis that relative deprivation has a absolute effect on quality of a nation's human resource (Wilkinson, 1994). If our hypothesis proves to be supported by the empirical evidence, it will come as little surprise to sociologists who have consistently found a close relationship between inequality and academic performance. The fact that at least a fifth of children in New Zealand, America and Britain now live in poverty is inevitably going to have an detrimental impact on the ability of these children to respond to educational opportunities and to recognise the relevance of formal study when living in neighbourhoods with high unemployment, crime and deprivation. Indeed, the importance of equity to the question of social learning is graphically illustrated in Julius Wilson's (1987) study of the urban underclass in America. He suggests that "... a perceptive ghetto youngster in a neighbourhood that includes a good number of working and professional families may observe increasing joblessness and idleness but he [sic] may also witness many individuals going to and from work; he may sense an increase in school dropouts but he can also see a connection between education and meaningful employment" ( $\mathrm{p}$. 56). He goes on to argue that the exodus of "respectable" middle and working class families from the inner city neighbourhoods in the 1970s and 1980s removed an important "social buffer" that could deflect the full impact of prolonged and increasing joblessness, given that the basic institutions in the area (churches, schools, stores, recreational facilities, etc.) are viable so long as more economically stable and secure families remained. Hence, the more social groups become isolated from one another, the fewer opportunities exist for the kind of social learning which even in the deprived neighbourhoods of New Zealand, American and British cities could offer role models to children, other than those which are now exist due to the "political economy of crack" (Davis, 1990).

Moreover, the impact of widening social inequalities is not restricted to children from ghetto or poor backgrounds; it also infects the social learning of the wealthier sections of the population. In a characteristically perceptive discussion, John Dewey noted that every expansive period of social history is marked by social trends which serve to "eliminate distance between peoples and classes previously hemmed off from one another" (Dewey, 1966, p. 100). At times where the opposite happens, it narrows the range of contacts, ideas, interests and role-models. The culture of the privileged tends to become "sterile, to be turned back to feed on itself; their art becomes a showy display and artificial; their wealth luxurious; their knowledge over-specialised; their manners fastidious rather than humane" (p. 98).

Hence the inequalities which the new consensus assumes will narrow, once there is proper investment in education and training, fails to recognise that the future wealth of nations depends upon a fundamental challenge to the inequalities of power underlying the distribution of income and educational opportunities. Therefore, the role of the nation state must increasingly become one of balancing the internal competition for a livelihood with a strategy geared towards upgrading the quality of education for all, through a reduction in relative inequalities. Moreover, a commitment to equality of opportunity is not only vital to the life-blood of a high skill economic strategy, but it provides a clear message to all sections of society that they are of equal worth and deserve genuine opportunities to fulfil their human potential.

\section{Conclusion}

The increasing importance attached to education in the global economy is not misplaced in the sense that nations will increasingly have to define the wealth of nations in terms of the quality of human resources among the population. The creation of a high skill, high wage, producer economy will depend upon an active state involved in investment, regulation and strategic planning in the economic infrastructure, alongside a commitment to skill formation through education and training. We have argued that such an economic strategy is necessary because it is the best way of creating a social dividend which can be used to fund a citizen's wage for all, given that the distributional problem can no longer be solved through employment within the division of labour. ${ }^{8}$ A social or citizen's wage which delivers families from poverty thereby becomes an important foundation for social justice, and desirable to create the educational conditions necessary if a country like New Zealand is to follow a high skill, high wage trajectory in the global economy (see Brown \& Lauder, forthcoming). Hence, if the potential of educational reform in the creation of a high skill economy is to be adequately addressed it follows that the least polarised and most secure societies in terms of income and job opportunity are likely to be the most efficient.

\section{Notes}

1. This paper is adapted and developed from one to appear in the Journal of Educational Policy, Jan/Feb, 1996, forthcoming. 
2 Equity can be defined in several ways. For example, it could be used to articulate a politics of difference whereby different systems of schooling (for example, Kaupapa Maori), develop different qualifications. Equity would therefore be seen as similar to parity of esteem, that is, that qualifications from different systems would be seen as commensurate. Such a position would reject Coleman's formulation of equality of results, because he clearly envisaged the same outcomes in terms of qualifications. However, in Aotearoa/New Zealand "equity" has largely been captured by the Right and as far as we can understand it, it means to the Right something like the notion we have in mind here.

3. While there is a new consensus between the major political parties regarding the key role of education, there are clearly also some differences which are discussed in the Journal of Educational Policy paper. Whether these differences are more than nuances remains to be seen.

4. The data cited here are compiled from the Independent on Sunday's economic indicators, 1994-1995 (April-March)

5. However, see the discussion in Kelsey (1995), Chapter 10.

6. The problem of distribution is that of determining how opportunities and income are to be apportioned. Under capitalism this is an ever-present problem because it is a system which is inherently unequal in its distribution of rewards and opportunities.

7. There is clearly a tension between the expansion of tertiary education and some varieties of right wing ideology. Friedman and Hayek, for example, have rejected the idea of mass tertiary education on the grounds that the pool of ability is not sufficiently large and that it entails a decline in standards. Interestingly, Hayek, like Bowles and Gintis, was concerned that graduate unemployment might lead to social unrest if not revolution!

8. For a feminist argument for a citizen's wage consistent with this position, see Pateman (1989).

\section{References}

Atkinson, J. (1985). The changing corporation. In D. Clutterbuck (Ed.) New patterns of work. Aldershot: Gower.

Blackburn, M., Bloom, D. \& Freeman, R. (1990). The declining economic position of less skilled American men. In G. Burtless (Ed.) A future of lousy jobs? Washington, DC: Brookings Institute.
Bound, J. \& Johnson, G. (1995). What are the causes of rising wage inequality in the United States? Economic Policy Review, Federal Reserve Bank of New York, 1(1), 9-17.

Brown, P. (1990). The "Third Wave": education and the ideology of parentocracy. British Journal of Sociology of Education, 11, 65-85.

Brown, P. (1995). Cultural capital and social exclusion: Some observations on recent trends in education, employment and the labour market. Work, Employment and Society, 9 (1), 29-51.

Brown, P. \& Scase, R. (1994). Higher education and corporate realities. London: UCL Press.

Brown, P. \& Lauder, H. (forthcoming) Capitalism and social progress in the twenty-first century.

Coleman, J. (1968, Winter). The concept of equality of educational opportunity. Harvard Educational Review, 38, 7-22.

Commission of the European Communities. (1993). Growth, competitiveness, employment: The challenges and ways forward into the 21st century. White Paper. Bulletin of the European Communities, 6/93.

Davis, M. (1990). City of quartz. New York: Verso.

Dewey, J. (1966). Democracy and education. New York: Free Press.

Dore, R. (1987). Taking Japan seriously. Athlone Press: London.

Eatwell, J. (1995). The international origins of unemployment. In J. Michie \& J. G. Smith (Eds.), Managing the global economy. Oxford: Oxford University Press.

Freeman, R. (1995). The limits of wage flexibility to curing unemployment. Oxford Review of Economic Policy, 11 (1), 63-72.

Gardiner, K. (1993). A survey of income inequality over the last twenty years: How does the UK compare? Welfare State Programme No. 100, Centre for Economics and Related Disciplines, London School of Economics.

Gosling, A. \& Machin, S. (1993). Trade unions and the dispersion of earnings in UK establishments, 1980-90. Centre for Economic Performance Discussion paper No. 140, London School of Economics.

Hills, J. (1995). Income and wealth - Volume two: a summary of the evidence. York: Joseph Rowntree Foundation.

Hirsch, F. (1977). Social limits to growth. London: Routledge.

Hutton, W. (1995). The state we're in. London: Jonathan Cape.

International Labour Organisation (ILO). (1995). World employment 1995. Geneva: ILO. 
Kelsey, J. (1995). The New Zealand Experiment. Auckland: Auckland University Press.

Lazonick, W. (1993). Industry clusters versus global webs: Organisational capabilities in the American economy. Industrial and Corporate Change, 2, 1-24.

Lindbeck, A. \& Snower, D. (1986). Wage setting, unemployment and insider-outsider relations. American Economic Review, 76, 235-239.

Marchak, M. P. (1991). The integrated circus: the New Right and the restructuring of global markets. Montreal: McGill-Queen's University Press.

Maurice, M., Sellier, F. \& Silvestre, J. (1986). The social foundations of industrial power. Cambridge, MA: MIT.

Newman, K. (1993). Declining fortunes. New York: Basic Books.

OECD. (1989). Education and the economy in a changing world. Paris: OECD.

OECD. (1993). Employment outlook. Paris: OECD.

OECD. (1994). Employment outlook. Paris: OECD.

Ormerod, P. (1994). The death of economics. London: Faber \& Faber.

Patel, P. \& Pavitt, K. (1991). Europe's technological performance. In C. Freeman, M. Sharp \& W. Walker (Eds.), Technology and the future of Europe. London: Pinter.

Pateman, C. (1989). The disorder of women, Ch. 8, Cambridge: Polity Press.

Peterson, W. (1994). Silent depression: The fate of the American dream. New York: W. W. Norton.

Reich, R. (1984). The next American frontier. Harmondsworth: Penguin.

Reich, R. (1991). The work of nations. London: Simon and Schuster.

Rowthorn, R. (1995). Capital formation and unemployment. Oxford Review of Economic Policy, 1 (1), 26-39.

Sengenberger, W. \& Wilkinson, F. (1995). Globalization and labour standards. In J. Michie \& J. G. Smith (Eds.), Managing the global economy. Oxford: Oxford University Press.

Snower, D. (1995). Evaluating unemployment policies: What do the underlying theories tell us? Oxford Review of Economic Policy, 11, 110-135.

Wilkinson, R. (1994). Unfair shares: The effect of widening income differences on the welfare of the young. Ilford: Barnardo's Publication.

Wilson, W. (1987). The truly disadvantaged. Chicago: University of Chicago Press.

Wood, A. (1994). North-south trade, employment and inequality: Changing fortunes in a skill-driven world. Oxford: Clarendon.

\section{The authors}

Phil Brown is Senior Lecturer, Department of Sociology, University of Kent. He has written, co-authored and edited several books, including Schooling Ordinary Kids. (1987). London: Tavistock, and (with DickScase) Higher Education and Corporate Realities. (1994). London: UCL. He is currently working on an anthology in the political economy of education with A. H. Halsey, Amy Stuart Wells and Hugh Lauder.

Hugh Lauder, Professor of Education, University of Bath, formerly Professor of Education at Victoria University of Wellington, is co-director of the Smithfield Project, with David Hughes (University of Canterbury). In addition to work on educational markets he has written on education and economic development with Phil Brown. 